Adam Kubów

Uniwersytet Ekonomiczny we Wrocławiu

\title{
Czy mieszkalnictwo w Polsce zmierza w kierunku standardów europejskich?
}

DOI: 10.19195/1643-0328.24.4

Słowa kluczowe: funkcje mieszkania, sytuacja mieszkaniowa UE, polskie programy mieszkaniowe

\section{Wprowadzenie}

Mieszkanie jest dobrem, które ma bardzo duże znaczenie dla prawidłowego funkcjonowania jednostki i społeczeństwa, dlatego też w krajach rozwiniętych państwo poprzez różne programy i instrumenty ułatwia jego dostępność. To ważne, gdyż mieszkanie jest dobrem bardzo drogim, którego zakup czy też wynajem wiąże się ze znacznymi wyrzeczeniami zabiegających o nie. Budownictwo mieszkaniowe nie tylko zaspokaja bardzo ważne potrzeby człowieka, lecz jest też istotnym czynnikiem rozwoju gospodarczego, albowiem rzutuje na rozwój wielu innych dziedzin gospodarki powiązanych $\mathrm{z}$ budową nowych zasobów mieszkaniowych czy też ich wyposażeniem i funkcjonowaniem.

Artykuł ma na celu przedstawienie sytuacji mieszkaniowej w Polsce w okresie członkostwa w Unii Europejskiej. Stanowi też próbę ukazania tej kwestii na tle innych krajów Unii Europejskiej, stawia jednocześnie pytanie, czy zauważane zmiany w polskim mieszkalnictwie zmierzają w kierunku rozwiązań europejskich ${ }^{1}$.

We wprowadzeniu warto przypomnieć, że do lat siedemdziesiątych dominowało w Polsce spółdzielcze budownictwo mieszkaniowe. Pod koniec lat siedemdziesiątych nastąpiły początki procesu prywatyzacji zasobu spółdzielczego, co wyraźnie nasiliło się po roku 1989. Jednocześnie następował proces wycofywania się państwa z aktywnego udziału w zaspokajaniu potrzeb mieszkaniowych. W wyniku tych zmian podstawowymi sposobami uzyskania mieszkania stały się budowa lub nabycie go na własność. Natomiast tradycyjna spółdzielczość mieszkaniowa bez finansowego wsparcia państwa niemal całkowicie odchodzi od budowy mieszkań lokatorskich.

${ }^{1}$ Ze względu na rozległy zakres problematyki w artykule omówione zostały tylko wybrane problemy. Pominięto między innymi politykę czynszową, dodatki mieszkaniowe czy społeczne budownictwo mieszkaniowe. 
Realizacja takiego kierunku w mieszkalnictwie doprowadziła do zastoju w budownictwie mieszkaniowym na początku lat dziewięćdziesiątych, a następnie do przyspieszonego rozwoju indywidualnego budownictwa mieszkaniowego prowadzonego w systemie gospodarczym oraz deweloperskiego, oferującego nabycie mieszkania na zasadach rynkowych. Pod koniec lat dziewięćdziesiątych nastąpiło również nieznaczne ożywienie działalności inwestycyjnej spółdzielni mieszkaniowych, stwarzających możliwość nabycia mieszkania również na zasadach rynkowych. W nowej rzeczywistości w szczególnie trudnej sytuacji znalazły się rodziny o przeciętnych i niskich dochodach. Naprzeciw ich potrzebom wyszło państwo, tworząc w 1995 r. Krajowy Fundusz Mieszkaniowy, którego celem było ułatwienie dostępu do mieszkania rodzinom o średnich dochodach poprzez finansowanie inwestycji realizowanych przez Towarzystwa Budownictwa Społecznego². Towarzystwa dzięki wsparciu państwa budują mieszkania na wynajem, jednakże czynsz w Towarzystwach Budownictwa Społecznego jest dość wysoki, gdyż TBS z części kwoty czynszu spłaca kredyt zaciągnięty w Krajowym Funduszu Mieszkaniowym. Tym samym mieszkania te nie są dostępne dla uboższej części społeczeństwa, a poza tym jest ich po prostu mało. W latach 2011-2015 wybudowano około 720 tys. mieszkań, z czego tylko $1 \%$ stanowiły mieszkania Towarzystwa Budownictwa Społecznego. Potrzeby mieszkaniowe uboższych rodzin mogą być zaspokojone dzięki budowie mieszkań gminnych. Ich udział w ogólnych zasobach powstałych w latach 2011-2015 był również nieznaczny i stanowił około 1,5\% ogółu wybudowanych mieszkań3.

Jak ważne jest mieszkanie w prawidłowym funkcjonowaniu rodziny, świadczą jego funkcje, a mianowicie:

- mieszkanie stwarza warunki do zaspokojenia ważnych biologicznych potrzeb człowieka, takich jak odżywianie, wypoczynek, sen;

- zapewnia poczucie bezpieczeństwa fizycznego i psychicznego;

- wpływa w istotny sposób na stan zdrowia człowieka czy też odgrywa istotną rolę w procesie jego przywracania;

- tworzy warunki do nauki, kształtowania ambicji i zainteresowań, tym samym wpływa na rozwój człowieka;

- stwarza możliwości do przygotowania do pracy czy wręcz jej wykonywania;

- odgrywa ważną rolę w kształtowaniu wzorców konsumpcji i stylów życia, na przykład przez stwarzanie warunków do racjonalnego sposobu odżywiania, dbałości o higienę i zdrowie;

- stanowi miejsce podstawowych procesów ważnych na każdym etapie rozwoju rodziny, jak na przykład rodzenie i opieka nad dziećmi, pielęgnacja osób chorych, opieka nad osobami starszymi;

2 M. Cesarski, Polityka mieszkaniowa w Polsce w pracach naukowych 1918-2010. Dokonania i wplyw polskiej szkoly badań, Warszawa 2013, s. 156-158.

3 Uchwała nr 115/2016 Rady Ministrów z dnia 27 września 2016 r. w sprawie przyjęcia Narodowego Programu Mieszkaniowego, s. 16, https://narodowyprogram.pl/wp-content/uploads/2017/03/uchwa\%C5\%82a_ narodowy_program_mieszkaniowy.pdf (dostęp: 16 kwietnia 2017). 
— sprzyja integracji społecznej, gdyż jest miejscem spotkań rodzinnych, przyjacielskich, sąsiedzkich ${ }^{4}$.

Znaczenie mieszkania w skali społecznej podkreślają między innymi badania CBOS, zwracające uwagę na fakt, że złe warunki mieszkaniowe w Polsce to ciągle bardzo istotny - spośród wielu innych - czynnik malejącej liczby urodzeń. Nie ma tu jednak bezpośredniej zależności, gdyż w 2000 r. czynnik ten jako bariera wzrostu dzietności był wymieniany najczęściej - przez trzy czwarte respondentów, a w 2012 przez połowę respondentów, natomiast dane statystyczne wskazują, że sytuacja mieszkaniowa w Polsce w tym okresie uległa poprawie, a współczynnik dzietności nie uległ zwiększeniu 5 .

\section{Sytuacja mieszkaniowa w Polsce na tle Unii Europejskiej}

W krajach Unii Europejskiej nie ma jednej wspólnej polityki mieszkaniowej, co nie oznacza, że Unia nie podejmuje żadnych działań w zakresie mieszkalnictwa. Polityka mieszkaniowa prowadzona przez UE przybiera postać bardziej ogólnych wytycznych, nakreślających kierunki zmian w mieszkalnictwie, niż zbiór wyraźnie adresowanych zadań. Takie rozwiązanie nie jest powszechnie uznawane za wystarczające. Obecnie pojawiają się bowiem wątpliwości, czy słuszne jest rozwiązanie pozostawiające sprawy mieszkaniowe poza polityką wspólnotową. Do argumentów przemawiających za stworzeniem spójnej polityki mieszkaniowej Unii Europejskiej zalicza się potrzebę objęcia regulacjami wielu aspektów związanych z aktualnymi problemami, jak trudna sytuacja mieszkaniowa ludzi młodych, konieczność podejmowania działań proekologicznych czy też nasilające się migracje. Natomiast wśród argumentów przeciw wymienia się głównie wysokie koszty polityki mieszkaniowej, które mogłyby znacznie obciążyć fundusze unijne ${ }^{6}$.

W wyniku istniejących rozwiązań w zakresie mieszkalnictwa w krajach Unii Europejskiej polityka mieszkaniowa państw unijnych jest dość różna, a sytuacja mieszkaniowa niekiedy bardzo istotnie zróżnicowana. Wielkość zasobów mieszkaniowych oraz ich jakość są wynikiem nie tylko realizowanej w danym kraju polityki mieszkaniowej. Niewątpliwie ta sytuacja zależy także od czynników o charakterze historycznym, kulturowym, politycznym oraz od uwarunkowań geograficznych. Dlatego też nie da się wypracować zestawu mierników, na których podstawie można by precyzyjnie określić sytuację mieszkaniową w poszczególnych krajach. Gdyby posłużyć się miernikiem najbardziej ogólnym w postaci liczby mieszkań przypadających na 1000 osób, to można zauważyć, że najkorzystniejszą sytuację mają obywatele większości krajów „Starej Unii”

${ }^{4}$ Por. A. Andrzejewski, Mieszkanie jako element środowiska materialnego i społecznego - funkcje i forma mieszkania, [w:] Przeszłość i przyszłość polskiej polityki mieszkaniowej, red. L. Frąckiewicz, Warszawa-Katowice 2005, s. 43-44.

${ }^{5}$ Polityka państwa wobec rodziny, BS/67/2012, CBOS, Warszawa 2012, s. 5, http://www.cbos.pl/SPISKOM.POL/2012/K_067_12.PDF (dostęp: 15 marca 2017).

${ }^{6}$ A. Zubrzycka-Czarnecka, Instrumenty i ograniczenia unijnej polityki mieszkaniowej, [w:] Europa socjalna. Iluzja czy rzeczywistość, red. W. Anioł, M. Duszczyk, P.W. Zawadzki, Warszawa 2011, s. 202-203. 
(bez krajów przyjętych w 2004 r. i później). Polska zajmuje dość słabą pozycję pod tym względem - wartość wskaźnika jest niższa o ponad 30\% od tych najwyższych w Unii (Grecja, Portugalia, Bułgaria, Francja, Hiszpania i Malta) ${ }^{7}$.

Tabela 1. Liczba mieszkań przypadająca na 1000 osób w krajach UE w 2015 r.

\begin{tabular}{l|c|l|l}
\hline Grecja (2011) & 573 & Szwecja & 476 \\
\hline Portugalia & 571 & Dania & 464 \\
\hline Bułgaria & 546 & Czechy (2011) & 454 \\
\hline Francja (2014) & 546 & Chorwacja (2013) & 451 \\
\hline Hiszpania (2011) & 540 & Holandia & 449 \\
\hline Malta (2011) & 539 & Węgry & 449 \\
\hline Finlandia & 536 & Litwa (2014) & 445 \\
\hline Włochy (2011) & 526 & Irlandia & 437 \\
\hline Austria & 525 & Wielka Brytania (2014) & 436 \\
\hline Niemcy & 510 & Rumunia (2011) & 432 \\
\hline Cypr (2010) & 510 & Luksemburg (2014) & 414 \\
\hline Estonia (2011) & 495 & Słowenia & 410 \\
\hline Łotwa (2011) & 493 & Polska (2014) & 363 \\
\hline Łotwa (2011) & 493 & Słowacja (2011) & 360 \\
\hline \multicolumn{2}{|l|}{ Średnia UE - 430 } \\
\hline
\end{tabular}

Źródło: OECD Questionnaire on Affordable and Social Housing, http://www.oecd.org/social/affordable-housingdatabase.htm (dostęp: 31 marca 2017).

Kierunki państw członkowskich Unii Europejskiej w sferze polityki społecznej określa Europejska Karta Społeczna z 1961 r. Karta nie tylko formułuje cele polityki społecznej, lecz także chroni zasadnicze prawa społeczne i ekonomiczne ludności, gdyż zobowiązuje kraje członkowskie do realizacji najważniejszych celów, w tym określonych w artykule 16 Prawo rodziny do ochrony społecznej, prawnej i ekonomicznej. Artykuł ów stanowi, że

W celu zapewnienia warunków niezbędnych do pełnego rozwoju rodziny, która jest podstawową komórką społeczeństwa, Umawiające się Strony zobowiązują się popierać ekonomiczną, prawną i społeczną ochronę życia rodzinnego, zwłaszcza poprzez takie środki, jak świadczenia społeczne i rodzinne, rozwiązania podatkowe, zachęcanie do budowania mieszkań dostosowanych do potrzeb rodzin, świadczenia dla młodych małżeństw oraz wszelkie inne stosowne środki ${ }^{8}$.

7 Por. P. Kurowski, P. Broda-Wysocki, Ubóstwo mieszkaniowe: oblicza, trendy, wyzwania, „Polityka Społeczna" 2017, nr 2.

${ }^{8}$ Europejska Karta Społeczna sporządzona w Turynie dnia 18 października 1961 r., Dz.U. z dnia 29 stycznia 1999 r., www.mpips.gov.pl/spoleczne-prawa-czlowieka/rada-europy-europejska-karta-spoleczna/ (dostęp: 20 marca 2017). 
W przytoczonym artykule zwrócono uwagę na zadania państwa w sferze kształtowania warunków mieszkaniowych rodziny. Bezpośrednio natomiast zadania te zostały zapisane w uchwalonej w 1996 r. Zrewidowanej Europejskiej Karcie Społecznej ${ }^{9}$. Karta ta jest jednym z najważniejszych dokumentów Rady Europy, określającym prawa i wolności, a także mechanizm kontrolny gwarantujący ich poszanowanie przez państwa będące stronami Karty. Rząd Polski przyjął ją w 2005 r. i tym samym zobowiązał się do realizacji prawa do mieszkania zapisanego w artykule 31 poprzez podejmowanie działań w następujących kierunkach:

1) popierania dostępu do mieszkań o odpowiednim standardzie;

2) zapobiegania i ograniczania bezdomności w celu jej stopniowego likwidowania;

3) uczynienia kosztów mieszkań dostępnymi dla osób, które nie mają wystarczających zasobów ${ }^{10}$.

$\mathrm{Na}$ znaczenie posiadania mieszkania dla prawidłowego funkcjonowania rodziny zwraca także uwagę Karta Praw Podstawowych Unii Europejskiej z 2007 r., w której choć nie ma odrębnych zapisów dotyczących prawa do mieszkania, to można je odnaleźć przynajmniej w dwóch artykułach. W artykule 7 Poszanowanie życia prywatnego i rodzinnego został sformułowany zapis: „Każdy ma prawo do poszanowania życia prywatnego i rodzinnego, domu i komunikowania się". W artykule 34 Zabezpieczenie społeczne i pomoc społeczna w punkcie 3 z kolei wyraźnie podkreślone zostały potrzeby, w tym mieszkaniowe uboższej części społeczeństwa:

W celu zwalczania wykluczenia społecznego i ubóstwa, Unia uznaje i szanuje prawo do pomocy społecznej i mieszkaniowej dla zapewnienia, zgodnie z zasadami ustanowionymi w prawie Unii oraz ustawodawstwach i praktykach krajowych, godnej egzystencji wszystkim osobom pozbawionym wystarczających środków.

Zapisy dotyczące prawa do mieszkania, choć niesformułowane bezpośrednio, można też dostrzec w artykułach 21 i 33 dotyczących niedyskryminacji oraz życia rodzinnego i zawodowego ${ }^{11}$.

Kierunki rozwoju mieszkalnictwa w krajach Unii Europejskiej można odnaleźć też w licznych rezolucjach Parlamentu Europejskiego, spośród których na szczególną uwagę zasługują te, w których sytuacja mieszkaniowa była mocno akcentowana. Należy do nich Rezolucja Parlamentu Europejskiego z dnia 10 maja 2007 r. w sprawie mieszkalnictwa i polityki regionalnej. Parlament, mając na uwadze, że prawo do mieszkania o odpowiednim, dobrym standardzie za rozsądną cenę jest ważnym podstawowym prawem, uznanym w niejednej karcie międzynarodowej i konstytucji krajowej, zwrócił w niej uwagę na istotne znaczenie mieszkania dla rozwoju regionu. Wyraża on opinię, że:

1) trudny dostęp do mieszkań, zwłaszcza dla mniej zamożnych rodzin, leży u podstaw zjawiska segregacji społecznej i powstawania gett;

${ }^{9}$ Zrewidowana Europejska Karta Społeczna, www.mpips.gov.pl/aktualnosci-wszystkie/art,5535,4326,podpisanie-zrewidowanej-europejskiej-karty-spolecznej.html (dostęp: 20 marca 2017).

${ }^{10}$ Ibidem.

11 Karta Praw Podstawowych Unii Europejskiej, Dziennik Urzędowy Unii Europejskiej 2007/C 303/1, http://bip.kprm.gov.pl/ftp/kprm/dokumenty/080226ulkarta.pdf (dostęp: 21 marca 2017). 
2) brak mieszkania rodzi dotkliwe problemy, jak bezdomność i wykluczenie społeczne;

3) inwestowanie w mieszkania socjalne odgrywa istotną rolę w udostępnianiu mieszkań tym osobom, dla których rynek mieszkaniowy jest niedostępny;

4) rozwój mieszkalnictwa prowadzi także do rozwoju infrastruktury społecznej, jak: ośrodki kultury, gabinety lekarskie, przedszkola, stadiony, miejsca spotkań itd., a w konsekwencji przeciwdziała alienacji i prowadzi do integracji społeczeństwa.

W rezolucji sformułowane zostały także oczekiwania pod adresem państw członkowskich, dotyczące między innymi:

1) przyjęcia niezbędnych przepisów ustawowych gwarantujących rzeczywiste prawo do mieszkania o odpowiednim, dobrym standardzie za przystępną cenę;

2) skoncentrowania uwagi władz krajowych i lokalnych na uruchomieniu instrumentów mających na celu ułatwienie młodym ludziom nabycie pierwszego mieszkania;

3) ściślejszej koordynacji przepływów finansowych i działań politycznych mających wpływ na mieszkalnictwo;

4) zainteresowania państw członkowskich pełnym wykorzystywaniem funduszy udostępnianych przez EFRR w dziedzinie mieszkalnictwa ${ }^{12}$.

Warto zwrócić uwagę, że w tej rezolucji szczególnie mocno zaakcentowany został problem dostępności mieszkań dla rodzin o umiarkowanych i niskich dochodach, co jeszcze wyraźniej ujęto w kolejnym akcie prawnym Unii Europejskiej. Rezolucja Parlamentu Europejskiego z dnia 11 czerwca 2013 r. w sprawie budownictwa socjalnego w Unii Europejskiej w całości została poświęcona dążeniom do stworzenia europejskiej polityki mieszkalnictwa socjalnego. W Rezolucji zawarty został zapis mówiący, że wydatki na mieszkalnictwo socjalne niekiedy niesłusznie są postrzegane wyłącznie jako koszty, gdyż w rzeczywistości dają one wiele korzyści w postaci lepszego samopoczucia społecznego i stanu zdrowia, rozwoju lokalnego rynku pracy, hamowania procesu zadłużania się gospodarstw domowych o niższych dochodach itp. ${ }^{13}$

Z przeglądu dokumentów wynika, że polityka mieszkaniowa prowadzona przez Unię Europejską przybiera postać wytyczania ogólnych kierunków. Unia Europejska nie ingeruje wyraźnie w politykę mieszkaniową państw członkowskich i niekiedy tym samym ogranicza możliwości realizacji potrzeb mieszkaniowych obywateli poszczególnych krajów.

$\mathrm{Z}$ dokumentami Unii Europejskiej korespondują też dokumenty krajowe. Artykuł 75 Konstytucji RP stanowi:

Władze publiczne prowadzą politykę sprzyjającą zaspokojeniu potrzeb mieszkaniowych obywateli, w szczególności przeciwdziałają bezdomności, wspierają rozwój budownictwa socjalnego oraz popierają działania obywateli zmierzające do uzyskania własnego mieszkania ${ }^{14}$.

12 Por. Rezolucja Parlamentu Europejskiego z dnia 10 maja 2007 r. w sprawie mieszkalnictwa i polityki regionalnej, http://www.europarl.europa.eu/sides/getDoc.do?pubRef=-//EP//TEXT+TA+P6-TA-2007-0183+0+DOC+XML+V0//PL (dostęp: 22 marca 2017).

13 Por. Rezolucja Parlamentu Europejskiego z dnia 11 czerwca 2013 r. w sprawie budownictwa socjalnego w Unii Europejskiej, http://www.europarl.europa.eu/sides/getDoc.do?pubRef=-//EP//TEXT+TA+P7-TA-2013-0246+0+DOC+XML+V0//PL (dostęp: 22 marca 2017).

14 Konstytucja Rzeczypospolitej Polskiej z dnia 2 kwietnia 1997 r., Dz.U. 1997 r. Nr 78, poz. 483. 
Niewątpliwie na zaspokojenie potrzeb mieszkaniowych wpływa nie tylko liczba mieszkań, ale także ich cechy, jak wielkość, stan techniczny, wyposażenie itp. Zbyt małe mieszkania nie stwarzają bowiem odpowiednich warunków do realizacji ważnych funkcji członków rodziny. Miernikiem wyrażającym dostosowanie mieszkania do wielkości rodziny i jej struktury jest wskaźnik przeludnienia ${ }^{15}$.

Średni wskaźnik przeludnienia w krajach Unii Europejskiej w 2015 r. wynosił 16,7\%. Mieszkania w Polsce są jednymi z najbardziej przeludnionych w Europie. Ponad 40\% polskich rodzin mieszka $\mathrm{w}$ zbyt małych mieszkaniach. W porównaniu z rokiem 2005 wskaźnik ten uległ jednak obniżeniu z poziomu 54,1\%. Dane Eurostatu pokazują, że wskaźniki przeludnienia zmniejszają się wraz z wiekiem członków rodziny. W mieszkaniach przeludnionych w Polsce $\mathrm{w} 2015 \mathrm{r}$. zamieszkiwało ponad 54,2\% rodzin z dziećmi do 18. roku życia i dwukrotnie mniej rodzin z osobami w wieku ponad 65 lat (27,2\%). Podobnie wysokie wskaźniki przeludnienia występują w większości pozostałych nowych krajów unijnych. Problem przeludnienia w niewielkim stopniu dotyczy krajów „starej Unii", albowiem w nich w mieszkaniach przeludnionych zamieszkuje średnio $12 \%$ rodzin, a w większości wyraźnie mniej. Jedynie we Włoszech i w Grecji wskaźnik przeludnienia mieszkań jest wyższy i sięga 30\%.

Tabela 2. Wskaźnik przeludnienia mieszkań w krajach UE w 2015 r.

\begin{tabular}{|c|c|}
\hline Udział w \% & Kraje \\
\hline Do 10 & $\begin{array}{l}\text { Cypr }(1,4) \text {, Belgia }(1,6) \text {, Holandia }(3,3) \text {, Irlandia }(3,4) \text {, Malta }(3,5) \text {, Hiszpania }(5,5) \text {, } \\
\text { Finlandia }(6,7) \text {, Luksemburg }(6,8) \text {, Niemcy }(7,0) \text {, Wielka Brytania }(7,3) \text {, Francja }(7,4) \text {, } \\
\text { Dania }(8,1)\end{array}$ \\
\hline $10-20$ & $\begin{array}{l}\text { Portugalia }(10,3) \text {, Szwecja }(11,6) \text {, Estonia }(13,4) \text {, Słowenia }(13,7) \text {, Austria }(15,0) \text {, } \\
\text { Czechy }(18,7)\end{array}$ \\
\hline $20-30$ & Litwa $(26,4)$, Włochy $(27,8)$, Grecja $(28,1)$ \\
\hline $30-40$ & Słowacja $(37,8)$ \\
\hline Powyżej 40 & $\begin{array}{l}\text { Węgry (41,1), Bułgaria }(41,4), \text { ), Łotwa }(41,4) \text {, Chorwacja }(42,1) \text {, Polska }(43,4) \text {, } \\
\text { Rumunia }(49,7)\end{array}$ \\
\hline UE - ogółem & UE $28(16,7)$, UE $18(12,0)$, UE (nowe kraje) $12(40,8)$ \\
\hline
\end{tabular}

Źródło: Opracowanie własne na podstawie: Eurostat (ilc_lvho05a) (dostęp: 14 kwietnia 2017).

Miernikiem bardziej złożonym niż wskaźnik przeludnienia jest wskaźnik poważnej deprywacji mieszkania, informujący o tym, że mieszkanie jest nie tylko przeludnione, lecz że jego stan techniczny i inne walory użytkowe są na niskim poziomie: w miesz-

15 Wskaźnik przeludnienia mieszkań definiuje się jako odsetek osób żyjących w lokalu nadmiernie zagęszczonym, tj. w gospodarstwach domowych, które nie dysponują liczbą mieszkań odpowiadającą następującym kryteriom: jedno pomieszczenie na jedno gospodarstwo domowe, na parę w gospodarstwie domowym, dla każdej osoby w wieku 18 lat i więcej, dla pary pojedynczych osób tej samej płci, między 12. a 17. rokiem życia, dla każdej osoby między 12 a 17 lat, a nie uwzględnionych w poprzedniej kategorii lub dla pary z dziećmi poniżej 12. roku życia. Eurostat (ilc_lvho05a) (dostęp: 14 kwietnia 2017). 
kaniu brakuje odpowiedniego wyposażenia w postaci bieżącej wody, toalety, ma ono przeciekający dach czy też jest niedostatecznie nasłonecznione. Również w tym wypadku Polska spośród krajów Unii Europejskiej wyróżnia się niekorzystnie. W 2015 r. 9,8\% polskich rodzin zamieszkiwało mieszkania zaliczane do grupy poważnej deprywacji. Warto jednak podkreślić, że w okresie 2005-2015 wskaźnik ten obniżył się z poziomu $29,7 \%$, a więc trzykrotnie. Podobnie jak w wypadku przeludnienia wyższe wskaźniki deprywacji mieszkania charakteryzują nowe kraje unijne. W Rumunii jest on najwyższy i sięga $20 \%$.

Tabela 3. Poważna deprywacja mieszkaniowa ${ }^{16}$ w krajach UE w 2015 r.

\begin{tabular}{|c|c|}
\hline Udział w \% & Kraje \\
\hline Do 2 & $\begin{array}{l}\text { Cypr }(0,5) \text {, Finlandia }(0,7) \text {, Belgia }(0,9) \text {, Holandia }(1,0) \text {, Irlandia }(1,1) \text {, Malta } \\
(1,3) \text {, Hiszpania }(1,5) \text {, Luksemburg }(1,7) \text {, Niemcy }(1,8) \text {, Szwecja }(2,0)\end{array}$ \\
\hline $2-5$ & $\begin{array}{l}\text { Dania }(2,8) \text {, Francja }(2,3) \text {, Wielka Brytania }(2,2) \text {, Czechy }(3,3) \text {, Austria }(4,3) \text {, Es- } \\
\text { tonia }(2,8) \text {, Słowacja }(4,2)\end{array}$ \\
\hline $5-10$ & $\begin{array}{l}\text { Portugalia }(4,7) \text {, Grecja }(6,7) \text {, Słowenia }(5,6) \text {, Chorwacja }(7,3) \text {, Włochy }(9,6) \text {, } \\
\text { Polska }(9,8)\end{array}$ \\
\hline Powyżej 10 & Litwa $(8,9)$, Bułgaria $(11,4)$, Łotwa $(15,5)$, Węgry $(15,5)$, Rumunia $(19,8)$ \\
\hline UE - ogółem & UE $28(4,9)$, UE 18 (3,5 strefa EURO), UE (nowe kraje) 12 (11,9 w 2014) \\
\hline
\end{tabular}

Źródło: Opracowanie własne na podstawie: Eurostat (ilc_mdho06a) (dostęp: 14 kwietnia 2017).

Informacji o sytuacji mieszkaniowej w Polsce dostarcza także status własności mieszkania. Polska należy do krajów Unii Europejskiej charakteryzujących się najwyższymi wskaźnikami własności lokali mieszkaniowych. Jest on jednak odzwierciedleniem nie zamożności obywateli, lecz przyjętego modelu polityki społecznej, w tym mieszkaniowej. Wcześniej, do roku 1989, dominował w Polsce socjalistyczny model polityki społecznej, charakteryzujący się tym, że państwo było podstawowym gwarantem bezpieczeństwa socjalnego obywateli ${ }^{17}$. W sferze mieszkaniowej wyrażał się on w dużym udziale państwa w zaspokajaniu potrzeb mieszkaniowych obywateli. Miało ono obowiązek zapewnienia mieszkań społeczeństwu, co nie oznaczało, że tylko państwo uczestniczyło w finansowaniu i udostępnianiu mieszkania. Wysoki udział lokali mieszkaniowych o charakterze własnościowym w Polsce wynika stąd, że podmioty kreujące rozwiązania z zakresu polityki mieszkaniowej po 1989 r. przyjęły stanowisko, według którego mieszkanie jest dobrem prywatnym, a tym samym zaspokojenie potrzeb mieszkaniowych należy przede wszystkim

16 Wskaźnik deprywacji materialnej definiuje się jako odsetek osób zajmujących mieszkania uważane za przeludnione, a zarazem odznaczające się występowaniem co najmniej jednego wyróżnika deprywacji mieszkaniowej, czyli np. brakiem toalety, zbyt małym naświetleniem, nieszczelnym dachem. Eurostat (ilc_mdho06a) (dostęp: 14 kwietnia 2017).

17 M. Księżopolski, Polska polityka społeczna na tle modeli występujących w Europie, [w:] Europa socjalna..., s. 277. 
do samych obywateli ${ }^{18}$. Tezę tę potwierdzają badania Eurostatu wskazujące na systematyczne zwiększanie się udziału własnościowych lokali mieszkaniowych w Polsce, z 62,5\% w 2007 r. do 83,7\% w 2015 r. W bogatszych krajach europejskich, jak np. Niemcy, Austria, Dania, a nawet w wielu nowych krajach unijnych, udział własnych lokali mieszkaniowych jest zdecydowanie niższy niż w Polsce. Warto też zauważyć, że w starych krajach unijnych wskaźnik ten systematycznie maleje, natomiast w nowych rośnie. W 2015 r. udział własnościowych lokali mieszkaniowych w krajach Unii Europejskiej zawierał się w przedziale 51,9-96,4\%, najniższy był w Niemczech, najwyższy zaś w Rumunii (tabela 4).

Tabela 4. Zamieszkiwanie we własnych lokalach własnościowych w krajach UE w 2015 r.

\begin{tabular}{l|l}
\hline \multicolumn{1}{c|}{ Udział w $\%$} & \multicolumn{1}{c}{ Kraje } \\
\hline $50-60$ & Niemcy $(51,9)$, Austria $(55,7)$ \\
\hline $60-70$ & $\begin{array}{l}\text { Dania }(62,7), \text { Wielka Brytania }(63,5), \text { Francja }(64,1), \text { Holandia }(67,8), \text { Irlandia }(70,0), \\
\text { Szwecja }(70,6)\end{array}$ \\
\hline $70-80$ & $\begin{array}{l}\text { Belgia }(72,0), \text { Luksemburg }(72,5), \text { Cypr }(72,9), \text { Włochy }(73,1), \text { Finlandia }(73,2), \text { Grecja } \\
(71,4), \text { Portugalia }(74,8), \text { Słowenia }(76,2), \text { Hiszpania }(78,2), \text { Czechy }(78,0), \text { Malta }(80,8),\end{array}$ \\
\hline $80-90$ & $\begin{array}{l}\text { Malta }(80,8), \text { Lotwa }(80,2), \text { Estonia }(81,5), \text { Polska }(83,7), \text { Bułgaria }(82,3), \text { Węgry }(86,3), \\
\text { Chorwacja }(89,7 \text { w 2014), Słowacja }(89,3), \text { Litwa }(89,4)\end{array}$ \\
\hline Powyżej 90 & Rumunia $(96,4)$ \\
\hline UE - ogółem & UE 28 (69,5), (70,1 w 2014), (70,7 w 2010) \\
\hline
\end{tabular}

Źródło: Opracowanie własne na podstawie: Eurostat (ilc_lvho02) (dostęp: 14 kwietnia 2017).

Wysokie koszty nabycia i utrzymania mieszkania są wyraźnym uszczerbkiem dochodów rodziny. W Polsce według badania Eurostatu prawie 10\% gospodarstw domowych obciążonych jest kosztami mieszkaniowymi przekraczającymi 40\% ich rozporządzalnych dochodów. Pod tym względem jednak średnia sytuacja w krajach Unii Europejskiej jest zbliżona. W wielu krajach ten udział jest wyraźnie niższy, na przykład na Malcie wynosi on tylko 1,1\%, na Cyprze 1,7\%, około 5\% w Irlandii, Finlandii i Francji, natomiast w Niemczech sięga 16\%, a w Grecji przekracza 40\%.

Tabela 5. Odsetek osób, których wydatki mieszkaniowe przekraczały $40 \%$ ekwiwalentnych dochodów do dyspozycji w $2015 \mathrm{r}$.

\begin{tabular}{|c|c|}
\hline Udział w \% & Kraje \\
\hline Do 5 & Malta $(1,1)$, Cypr $(1,7)$, Irlandia $(4,6)$, Finlandia $(4,9)$ \\
\hline $5-10$ & $\begin{array}{l}\text { Francja }(5,7) \text {, Słowenia }(6,1) \text {, Luksemburg }(6,0) \text {, Austria }(6,4) \text {, Estonia }(6,8) \text {, Chorwacja } \\
(7,2) \text {, Szwecja }(7,5) \text {, Łotwa }(8,1) \text {, Węgry }(8,5) \text {, Włochy }(8,6) \text {, Polska }(8,7) \text {, Słowacja }(9,1) \text {, } \\
\text { Litwa }(9,1) \text {, Portugalia }(9,1) \text {, Belgia }(9,4)\end{array}$ \\
\hline
\end{tabular}

18 J. Supińska, A. Zubrzycka-Czarnecka, Polskie mieszkalnictwo w erze integracji europejskiej - punkt wyjścia, ścieżki rozwoju, [w:] Dekada członkostwa w Unii Europejskiej. Perspektywa polityki społecznej, red. C. Żołędowski, B. Rysz-Kowalczyk, M. Duszczyk, Warszawa 2015, s. 288. 


\begin{tabular}{l|l}
\hline Powyżej 10 & $\begin{array}{l}\text { Hiszpania }(10,3), \text { Czechy }(10,4), \text { Wielka Brytania }(12,5), \text { Bułgaria }(14,8), \text { Holandia }(14,9), \\
\text { Dania }(15,1), \text { Niemcy }(15,6), \text { Rumunia }(15,9), \text { Grecja }(40,9)\end{array}$ \\
\hline $\begin{array}{l}\text { UE } \\
\text { ogółem }\end{array}$ & UE 28 (11,3), UE 18 (11,2), UE 12 (nowe kraje) $(11,1)$ \\
\hline
\end{tabular}

Źródło: Opracowanie własne na podstawie: Eurostat (ilc_lvho07a) (dostęp: 14.04.2017).

Mniej korzystny obraz obciążenia rodziny wydatkami na cele mieszkaniowe w Polsce kształtuje się w oparciu o wyniki badań Diagnoza Społeczna 2015. Wskazują one bowiem na utrzymujący się na dość wysokim poziomie udział gospodarstw domowych zalegających z opłatami za mieszkanie oraz za gaz i energię elektryczną. W 2015 r. ze stałymi opłatami za czynsz zalegało $5,5 \%$ gospodarstw domowych, a $\mathrm{z}$ opłatami za gaz i energię elektryczną - około 2,5\%. Znacznie gorsza sytuacja miała miejsce w rodzinach utrzymujących się z niezarobkowych źródeł oraz w rodzinach niepełnych, w których zaległości za czynsz miała co piąta rodzina. Ponadto około 1,4\% gospodarstw domowych zalegało ze spłatą kredytu mieszkaniowego. W porównaniu z odpowiednimi danymi dotyczącymi roku 2000 uległy one jednak znacznemu obniżeniu — o około połowę ${ }^{19}$.

Ogólna ocena sytuacji mieszkaniowej w Polsce na tle innych krajów Unii Europejskiej wypada ostatecznie dość niekorzystnie, natomiast zmiany, jakie zaszły w obszarze mieszkalnictwa w Polsce w okresie członkostwa w Unii Europejskiej, są raczej pozytywne. Niewątpliwie pozytywnie należy ocenić spadek wskaźników przeludnienia mieszkania i deprywacji mieszkania. Z obawą jednak można patrzeć na samo podejście podmiotów tworzących rozwiązania w sferze mieszkalnictwa, które traktują mieszkanie jako dobro prywatne, o które troszczyć muszą się głównie same rodziny. Takie podejście ogranicza dostęp do mieszkań przez rodziny mniej zamożne lub też obarcza je nadmiernymi obowiązkami finansowymi prowadzącymi do zadłużenia.

\section{Programy na rzecz poprawy sytuacji mieszkaniowej w Polsce}

W Polsce w okresie od 2006 r. realizowano kilka programów mieszkaniowych. Warto więc zadać pytanie, w jakim kierunku one zmierzały. Czy utrzymujące się dość dobre wyniki w budownictwie mieszkaniowym wyraźnie poprawiły sytuację mieszkaniową Polaków? Mimo zwiększenia dostępności mieszkaniowych kredytów hipotecznych i znacznego ożywienia budownictwa mieszkaniowego znaczna część społeczeństwa polskiego nie jest $\mathrm{w}$ stanie zainwestować $\mathrm{w}$ zakup mieszkania. Podstawową barierą są niskie płace w stosunku do rynkowych cen nieruchomości oraz wysokie koszty budowy mieszkań. W największych miastach w Polsce za przeciętną pensję można kupić jedynie okoto $0,5-0,6 \mathrm{~m}^{2}$ mieszkania. Natomiast w krajach zachodnioeuropejskich jest to $4-5$ razy więcej. Deficyt mieszkań występuje przede wszystkim w dużych miastach. Czynniki te powodują, że nadal bez możliwości zakupu mieszkania pozostaje znaczna grupa ludzi,

19 Diagnoza Społeczna 2015. Warunki i jakość życia Polaków, red. J. Czapiński, T. Panek, Warszawa 2015, s. 92-94, http://www.diagnoza.com (dostęp: 2.04.2017). 
zwłaszcza młodych, a jeszcze większa część rodzin zamieszkuje lokale o niskim standardzie, co niewątpliwie ogranicza ich rozwój, a także niekorzystnie wpływa na przyrost naturalny ludności.

Tabela 6. Statystyczny deficyt mieszkaniowy w Polsce w latach 2002, 2011 i 2015 w tys.*

\begin{tabular}{l|c|c|c}
\hline \multicolumn{1}{c|}{ Wyszczególnienie } & 2002 & 2011 & 2015 \\
\hline Liczba gospodarstw domowych & 13337 & 13568 & $14000^{* * *}$ \\
\hline Liczba mieszkań zamieszkanych & 11764 & 12525 & 13103 \\
\hline Deficyt mieszkań bezwzględny ${ }^{* *}$ & 1573 & $1043^{* *}$ & 897 \\
\hline Wskaźnik deprywacji mieszkaniowej & ok. $30 \%$ & $11,4 \%$ & $9,8 \%$ \\
\hline Liczba mieszkań o niskim standardzie & 3529 & 1428 & 1284 \\
\hline Łączny deficyt mieszkań & 5102 & 2471 & 2181 \\
\hline
\end{tabular}

*Pokazane w tabeli obliczenia deficytu mieszkaniowego, mające charakter szacunkowy, dają przybliżoną wielkość niedoborów. Dlatego też wielkości deficytu mieszkaniowego podawane w różnych opracowaniach mogą się różnić. Można założyć, że obecnie deficyt jest nieco mniejszy, co wynikać może z przyrostu zasobów mieszkaniowych oraz obniżenia się wskaźnika deprywacji mieszkaniowej.

${ }^{* *}$ Nie uwzględnia kategorii ludności rezydującej.

*** Szacunki Ministerstwa Infrastruktury i Budownictwa.

Źródło: Uchwała nr 115/2016 Rady Ministrów z dnia 27 września 2016 r. w sprawie przyjęcia Narodowego Programu Mieszkaniowego, s. 5, https://narodowyprogram.pl/wp-content/uploads/2017/03/uchwa\%C5\%82a_narodowy_program_ mieszkaniowy.pdf 16.04.2017 oraz obliczenia własne na podstawie: Eurostat (ilc_mdho06a) (dostęp: 16 kwietnia 2017).

Szacunkowe obliczenia pozwalają sądzić, że około miliona rodzin w Polsce nie posiada samodzielnego mieszkania, a kolejnych ponad milion rodzin zamieszkuje lokale o obniżonym standardzie. Tak obliczony deficyt mieszkaniowy wskazuje, że 2,2 mln rodzin ma niezaspokojone potrzeby mieszkaniowe. Warto jednak zauważyć, że w okresie pomiędzy dwoma ostatnimi Narodowymi Spisami Powszechnymi sytuacja mieszkaniowa w Polsce uległa znacznej poprawie i w czterech kolejnych latach po spisie z $2011 \mathrm{r}$. proces ten nadal wykazywał pozytywną tendencję. W latach 2002-2015 bezwzględny deficyt mieszkaniowy obniżył się o ponad $40 \%$, a liczba mieszkań o obniżonym standardzie - co wynika z wyraźnego obniżenia wskaźnika deprywacji mieszkaniowej spadła o ponad $60 \%$.

Ten wyraźny przyrost zasobów mieszkaniowych, jak i poprawa jakości mieszkań w Polsce mogły dokonać się między innymi w wyniku rosnących dochodów społeczeństwa oraz rosnących nakładów państwa na mieszkalnictwo. Analizując wydatki państwa na cele mieszkaniowe w latach 2005-2016, zauważyć można ich wzrost o 65\%. Wzrost wydatków przeznaczony był na remonty istniejących zasobów mieszkaniowych (Fundusz Termomodernizacji i Remontów), a przede wszystkim na Fundusz Dopłat promujący te cele mieszkaniowe, które wykazywane są w dokumentach Unii Europejskiej, a więc rozwój budownictwa mieszkaniowego na rzecz młodych rodzin nieposiadających własnego mieszkania. W strukturze wydatków jest również niepokojąca informacja: ciągle niewielki jest udział wydatków na budownictwo socjalne, a w 2009 r. uległ likwidacji 
Krajowy Fundusz Mieszkaniowy, który był źródłem wsparcia społecznego budownictwa czynszowego $^{20}$. Ponadto dość znaczną część budżetu, choć stale malejącą, pochłaniają wydatki na stare zobowiązania, które nie służą zaspokajaniu aktualnie występujących potrzeb mieszkaniowych.

Tabela 7. Bezpośrednie wydatki budżetu państwa na cele mieszkaniowe w latach 2005-2016 (w mln zł)

\begin{tabular}{|c|c|c|c|c|c|c|c|c|c|}
\hline Wydatki/lata & 2005 & 2009 & 2010 & 2011 & 2012 & 2013 & 2014 & 2015 & 2016 \\
\hline \multicolumn{10}{|c|}{ Budownictwo mieszkaniowe } \\
\hline „Rodzina na swoim” & & 60 & 255 & 439 & 689 & 800 & 595 & 360 & 383 \\
\hline $\begin{array}{l}\text { „Mieszkanie dla } \\
\text { Młodych” }\end{array}$ & & & & & & & 207 & 521 & 701 \\
\hline Budownictwo socjalne & 21 & 45 & 40 & 80 & 120 & 90 & 80 & 80 & 137 \\
\hline $\begin{array}{l}\text { Krajowy Fundusz } \\
\text { Mieszkaniowy }\end{array}$ & 165 & 150 & & & & & & & \\
\hline
\end{tabular}

Termomodernizacja i remonty

\begin{tabular}{l|c|c|c|c|c|c|c|c|c}
\hline $\begin{array}{l}\text { Program } \\
\text { termomodernizacji } \\
\text { i remontów }\end{array}$ & 115 & 109 & 0 & 260 & 120 & 133 & 330 & 120 & 50 \\
\hline Kredyty „powodziowe” & 3 & 1 & 1 & 1 & 2 & 1 & 1 & 0 & 0 \\
\hline
\end{tabular}

Stare zobowiązania

\begin{tabular}{l|c|c|c|c|c|c|c|c|c}
\hline $\begin{array}{l}\text { Refundacja premii } \\
\text { gwarancyjnych }\end{array}$ & 385 & 403 & 429 & 445 & 435 & 398 & 303 & 242 & 213 \\
\hline $\begin{array}{l}\text { Stare kredyty } \\
\text { mieszkaniowe }\end{array}$ & 233 & 147 & 138 & 143 & 119 & 75 & 52 & 40 & 37 \\
\hline Ogółem & 922 & 915 & 863 & 1368 & 1485 & 1497 & 1568 & 1363 & 1521 \\
\hline$\%$ PKB & 0,07 & 0,06 & 0,06 & 0,09 & 0,09 & 0,09 & 0,09 & 0,08 & 0,08 \\
\hline $\begin{array}{l}\% \text { wydatków budżetowych } \\
\text { ogółem }\end{array}$ & 0,31 & 0,31 & 0,29 & 0,45 & 0,47 & 0,47 & 0,50 & 0,41 & 0,42 \\
\hline
\end{tabular}

Źródło: Bezpośrednie wydatki budżetu państwa na sferę mieszkaniową, http://mib.gov.pl/files/0/1796792/Wydatkibudzetupanstwanasferemieszkaniowaod1995.pdf (dostęp: 14 kwietnia 2017).

W kontekście kierunków zmian w mieszkalnictwie w Polsce warto przyjrzeć się programom mieszkaniowym realizowanym w Polsce. W celu poprawy warunków mieszkaniowych młodych rodzin w 2006 r. został uruchomiony system preferencyjnych kredytów z dopłatą rządową pod nazwą „Rodzina na swoim”. Istotą programu była (i jest) pomoc państwa $\mathrm{w}$ spłacie kredytu przez okres ośmiu lat $\mathrm{w}$ wysokości połowy naliczonych odsetek. Z programu mogły skorzystać przede wszystkim rodziny, które nie były właścicielami mieszkania lub domu, pod warunkiem, że nieruchomość była położona

20 A. Muzioł-Więcławowicz, Problemy mieszkaniowe Polaków a polska polityka mieszkaniowa, [w:] Mieszkalnictwo w Polsce, red. M. Salamon, A. Muzioł-Więcławowicz, Warszawa 2015, s. 75-77. 
na terytorium Polski, a jej powierzchnia nie przekraczała $75 \mathrm{~m}^{2} \mathrm{w}$ przypadku kupowanego mieszkania i $140 \mathrm{~m}^{2} \mathrm{w}$ przypadku domu ${ }^{21}$.

Zainteresowanie kredytem było duże i w ciągu 7 lat trwania programu „Rodzina na swoim” przyznano 192360 kredytów mieszkaniowych z dopłatą rządową, dzięki czemu ponad 192 tysiące gospodarstw domowych nabyło własne mieszkanie. Ponadto program „RnS” w wielu wypadkach był czynnikiem przyspieszającym podjęcie decyzji o nabyciu własnego lokalu mieszkalnego bądź domu jednorodzinnego.

Tabela 8. Liczba i wartość udzielonych kredytów w programie „Rodzina na swoim” w latach 2007-2013

\begin{tabular}{l|c|c|c|c|c|c|c|c}
\hline \multicolumn{1}{c|}{ Wyszczególnienie } & 2007 & 2008 & 2009 & 2010 & 2011 & 2012 & 2013 & Ogółem \\
\hline $\begin{array}{l}\text { Liczba udzielonych } \\
\text { kredytów }\end{array}$ & 4001 & 6645 & 30882 & 43120 & 51328 & 45792 & 10592 & 192360 \\
\hline $\begin{array}{l}\text { Wartość udzielonych } \\
\text { kredytów (w mln zł) }\end{array}$ & 434,7 & 852,8 & 5417,6 & 8074,3 & 10249,3 & 7939,3 & 2004,6 & 34972,6 \\
\hline
\end{tabular}

Źródło: Dane liczbowe programu ,,Rodzina na swoim”, Bank Gospodarstwa Krajowego 2014, www.bgk.pl/files/ public/Pliki/Klienci_indywidualni/rodzina_na_swoim/Dane_liczbowe_do_31_grudnia_2013.pdf (dostęp: 24 marca 2017).

W okresie funkcjonowania programu, tj. do roku 2013, wyraźnie wzrosło zainteresowanie kredytami z dopłatami państwa, co powodowało, że stawał się on coraz bardziej kosztowny. Program „Rodzina na swoim” spotkał się z różnymi ocenami, zarówno pozytywnymi, jak i negatywnymi. Niewątpliwie jego zaletą było to, iż przyczynił się on do pobudzenia budownictwa mieszkaniowego. Natomiast negatywnie oceniano go ze względu na utrudnioną dostępność preferencyjnego kredytu, wynikającą z ograniczonej zdolności kredytowej ludzi młodych. W rezultacie rodziny mniej zamożne rzadko korzystały z tego kredytu lub w ogóle pozbawione były takiej możliwości. Nie poprawił on tym samym sytuacji mieszkaniowej rodzin mniej zamożnych, które ze względu na niskie dochody nie mogły uzyskać kredytu. Pewną wadą programu był także fakt, iż ze względu na wysokie ceny $\mathrm{m}^{2}$ mieszkania rosło zainteresowanie głównie mieszkaniami małymi, co obniżyło tempo spadku wskaźnika przeludnienia mieszkania ${ }^{22}$.

Po zakończeniu programu „Rodzina na swoim”, aby pomóc młodym rodzinom w nabyciu mieszkania w 2014 r., rząd uruchomił nowy program „Mieszkanie dla Młodych”. Program ten nie zmienił kierunku w polityce mieszkaniowej, gdyż również jest kierowany raczej do rodzin dobrze zarabiających, choć jest bardziej przyjazny rodzinom. W odróżnieniu od poprzedniego jest łatwiej dostępny, gdyż stwarza możliwość otrzymania od państwa dopłaty do wkładu własnego, niezbędnego przy ubieganiu się o kredyt hipoteczny na zakup mieszkania czy budowę domu. Program rządowy „Mieszkanie dla Młodych” pomaga ro-

21 Ustawa z dnia 8 września 2006 r. o finansowym wsparciu rodzin w nabywaniu własnego mieszkania, Dz.U. z 2006 r. Nr 183, poz. 1354 ze zm.; ustawa z dnia 15 lipca 2011 r. o zmianie ustawy o finansowym wsparciu rodzin w nabywaniu własnego mieszkania oraz niektórych innych ustaw, Dz.U. z 2011 r. Nr 168, poz. 1006.

22 Por. poprzedni punkt artykułu. 
dzinie zgromadzić wymagany przez banki wkład własny, który w latach 2014-2015 kształtował się na poziomie co najmniej 10\% kwoty wnioskowanego kredytu (od 2016 r. 15\%).

Zaletą programu jest również fakt, że promuje on wielkość rodziny. Otóż osoby samotne bądź małżeństwa bezdzietne mają prawo starać się o dopłatę do wkładu własnego w wysokości $10 \%$ wnioskowanego kredytu. Natomiast osoby oraz małżeństwa wychowujące minimum jedno dziecko mają możliwość skorzystania z dopłaty do wkładu własnego w wysokości $15 \%$, wychowujące dwoje dzieci - 20\%, a wychowujące przynajmniej troje dzieci $-30 \%$. Wraz z rozwojem rodziny zwiększa się więc powierzchnia mieszkania objęta dopłatą. Bazowa wielkość mieszkania została ustalona na poziomie do $50 \mathrm{~m}^{2}$, natomiast $\mathrm{w}$ wypadku rodzin $\mathrm{z}$ trójką dzieci lub liczniejszych wielkość ta została podwyższona do $65 \mathrm{~m}^{2}$. Powierzchnie mieszkań mogą być większe, jednakże dodatkowa powierzchnia nie jest już objęta dopłatą. Dopłata natomiast nie przysługuje, jeśli powierzchnia mieszkania przekroczy $75 \mathrm{~m}^{2}$, a w wypadku rodzin z trójką dzieci $85 \mathrm{~m}^{2}$. Przy zakupie domu jednorodzinnego górne granice powierzchni zostały ustalone na poziomie 100 lub $110 \mathrm{~m}^{2}$. Jego realizacja tym samym przyczynić się może do dalszego obniżenia wskaźnika przeludnienia mieszkań.

Prorodzinny charakter programu „MdM” wyraża się także w tym, że przewiduje on dodatkowe wsparcie dla tych kredytobiorców, którym w ciągu 5 lat od nabycia mieszkania liczba dzieci zwiększy się o trzecie lub kolejne po nim. Wsparcie to ma charakter jednorazowej spłaty części kredytu w wysokości 5\% jego wartości ${ }^{23}$. Na dopłaty w całym okresie funkcjonowania programu, tj. lata 2014-2018, rząd założył przeznaczenie ponad 3,4 mld złotych.

Tabela 9. Liczba i kwota dofinansowania wniosków zaakceptowanych przez banki w Programie „Mieszkanie dla Młodych” w latach 2014-2016

\begin{tabular}{l|c|c|c|c|c|c|c|c}
\hline Wyszczególnienie & 2014 & 2015 & $\begin{array}{r}\text { I kw. } \\
2016\end{array}$ & $\begin{array}{c}\text { II kw. } \\
2016\end{array}$ & $\begin{array}{c}\text { III kw. } \\
2016\end{array}$ & $\begin{array}{c}\text { IV kw. } \\
2016\end{array}$ & 2016 & Ogółem \\
\hline $\begin{array}{l}\text { Liczba } \\
\text { zaakceptowanych } \\
\text { wniosków }\end{array}$ & 15972 & 30901 & 15342 & 8099 & 2650 & 2320 & 28411 & 75284 \\
\hline $\begin{array}{l}\text { Kwota } \\
\text { dofinansowania } \\
\text { (w mln zł) }\end{array}$ & 366,2 & 767,4 & 415,1 & 230,0 & 71,8 & 77,7 & 794,6 & 1928,2 \\
\hline
\end{tabular}

Źródło: Raport AMRON-SARFiN. Ogólnopolski Raport o Kredytach mieszkaniowych i cenach transakcyjnych nieruchomości, nr 1/2014-4/2016, http://zbp.pl/raporty/raport-amron-sarfin (dostęp: 18 kwietnia 2017).

Zainteresowanie programem „MdM” jest bardzo duże i wykazuje tendencję rosnącą. Od jego uruchomienia, tj. od 1 stycznia 2014 do końca 2016 r., do dofinansowania zaakceptowano ponad 75 tys. wniosków, a kwota dofinansowania osiągnęła prawie dwa miliardy złotych. Pozostała kwota, tj. 1,4 mld złotych, została zarezerwowana do wykorzystania w latach 2017 i 2018. O dużym zainteresowaniu programem świadczy także

${ }^{23}$ Mieszkanie dla młodych, http://mib.gov.pl/2-MieszkaniedlaMlodych.htm (dostęp: 18 kwietnia 2017). 
fakt, że przyjmowanie wniosków z terminem wypłaty w kolejnych latach kończyło się często już pod koniec II kwartału roku poprzedniego.

Oba realizowane programy zasługują na pozytywną ocenę z punktu widzenia szeroko rozumianej polityki mieszkaniowej przede wszystkim dlatego, że stworzyły warunki sprzyjające zaspokojeniu potrzeb mieszkaniowych dla wielu młodych rodzin. Także pozytywna ocena programów może być sformułowana z punktu widzenia rozwoju budownictwa mieszkaniowego i rynku nieruchomości. Im więcej mieszkań na rynku, tym nie tylko lepsze zaspokojenie potrzeb wynikające $\mathrm{z}$ jego posiadania, ale także z powodu zwiększenia się podaży mieszkań na wynajem, a to może skutkować obniżką cen wynajmu. Istotnym mankamentem programów była ich dostępność wynikająca z ograniczonej zdolności kredytowej młodych rodzin. Tym samym nie rozwiązują one podstawowego problemu polskiego mieszkalnictwa, a mianowicie ograniczonej dostępności mieszkań dla rodzin o przeciętnych i niskich dochodach. Oba programy charakteryzuje nastawienie na wsparcie budownictwa własnościowego, a więc utrwalają one już bardzo wysoki udział w polskim mieszkalnictwie, w odróżnieniu od bogatszych krajów europejskich, zasobów mieszkań własnościowych.

Wyraźnie innym rozwiązaniem jest program rządowy „Mieszkanie Plus”, którego realizacja ma rozpocząć się w 2018 r. Program ma opierać się w największym stopniu o tanie budownictwo spółdzielcze oraz społeczne i ma być finansowany przez fundusz inwestycyjny Banku Gospodarstwa Krajowego, zwany Funduszem Mieszkanie Plus. Jego główną ideą jest budowa tanich mieszkań na wynajem o umiarkowanych czynszach, z możliwością docelowego przeniesienia prawa własności. W założeniach mieszkania będą budowane tylko i wyłącznie na gruntach państwowych, przez co cena budowy $\mathrm{m}^{2}$ nie powinna przekraczać 3 tysięcy zł. Czynsz za wynajem miałby zawierać się w przedziale $10-20 \mathrm{zł} \mathrm{za} \mathrm{m}^{2}$, natomiast $\mathrm{w}$ dużych miastach byłby on wyższy o około $5 \mathrm{zł}$. Niezależnie od czynszu wynajmujący mieszkanie ponosiłby koszty zużycia mediów. Jeśli wynajmujący zdecyduje się na wybór opcji dochodzenia do własności, to wtedy będzie zobowiązany do płacenia $20 \%$ wyższego czynszu. Okres dochodzenia do własności wynosiłby 25-30 lat w zależności od wartości mieszkania.

Założenia programu „Mieszkanie Plus” wskazują na jego zalety, do których oprócz już wspomnianych zaliczyć można także to, że w porównaniu z poprzednimi nie przewiduje on ograniczeń wiekowych najemcy czy też właściciela mieszkania.

Program jest kierowany przede wszystkim do tych rodzin, których potrzeby mieszkaniowe $\mathrm{w}$ warunkach istniejących rozwiązań pozostawały trudne do zaspokojenia. Zakłada on bowiem, że korzystać z niego będą głównie te rodziny, których dochody były zbyt niskie, żeby mogły one decydować się na zakup własnego mieszkania, jak i te, których dochody były zbyt wysokie, żeby mogły one liczyć na otrzymanie mieszkania pozostającego w zasobach gminy.

Program „Mieszkanie Plus” spotkał się z aprobatą ekspertów Polskiego Związku Firm Deweloperskich (PZFD), którzy wyrażają opinię, że takie wsparcie rynku mieszkaniowego ze strony państwa jest potrzebne, albowiem przyczyni się do ograniczenia deficytu mieszkań. Obawiają się oni jednak tego, że utrzymanie niskiej ceny budowy mieszkań 
na państwowych gruntach, często niedoinwestowanych, może prowadzić do obniżenia standardu mieszkań, braku infrastruktury okołomieszkaniowej, a w konsekwencji do wzrostu kosztów eksploatacji mieszkań. Istnieją także obawy, czy koncentracja środków finansowych na programie „Mieszkanie Plus” nie spowoduje wycofania się państwa ze wspierania rozwoju innych form budownictwa mieszkaniowego, jak budownictwo komercyjne na wynajem, spółdzielcze, czynszowe czy komunalne ${ }^{24}$. W kontekście oceny programu powstaje także pytanie, czy rzeczywiście wybudowane mieszkania w ramach programu będą dostępne dla rodzin o przeciętnych i niskich dochodach, jeśli sam wynajem może wiązać się z kosztem 25 zł za m² mieszkania.

Program „Mieszkanie Plus” jest tylko częścią Narodowego Programu Mieszkaniowego, który został przyjęty uchwałą Rady Ministrów 27 września 2016 r. ${ }^{25}$ Jest to dokument o charakterze strategiczno-programowym, który w sposób kompleksowy ujmuje cele polityki mieszkaniowej państwa.

Podstawą opracowania Narodowego Programu Mieszkaniowego była analiza sytuacji mieszkaniowej w Polsce ze szczególnym uwzględnieniem negatywnych zmian zaobserwowanych w latach 2011-2015. Do charakterystycznych cech tego okresu należy zaliczyć:

- niekorzystną z punktu widzenia dostępności mieszkań strukturę nowego budownictwa mieszkaniowego: $97,1 \%$ stanowiły mieszkania niedostępne dla mniej zamożnych rodzin. Dominowało bowiem budownictwo indywidualne, najczęściej polegające na budowie domów jednorodzinnych systemem gospodarczym (ok. 54,4\%) oraz budownictwo deweloperskie i mające podobne cechy nowe budownictwo spółdzielcze (ok. 42,7\%).

- niski udział w nowych zasobach mieszkaniowych budownictwa społecznego, które służy potrzebom osób o przeciętnych i niskich dochodach. Budownictwo gminne i Towarzystw Budownictwa Społecznego (oraz śladowe ilości nowych mieszkań zakładowych) stanowiło tylko 2,5\% nowo wybudowanych zasobów. W latach 2011-2015 jego udział w całości nowych mieszkań obniżył się z 3,4\% do 2,0.

- nasilający się proces prywatyzacji zasobów mieszkaniowych gminy. Proces ten polegał na sprzedaży mieszkań dotychczasowym najemcom oraz zwrotach mieszkań dawnym właścicielom lub ich spadkobiercom. Rozmiary nowego budownictwa gminnego niwelowały roczny ubytek tych zasobów tylko w około $7 \%{ }^{26}$.

Odpowiedzią na zaprezentowane problemy są trzy podstawowe cele Narodowego Programu Mieszkaniowego oraz założone w nim mierniki planowane do osiągnięcia do roku 2030:

24 Potrzebne, choć nierealne - deweloperzy nie boją się „Mieszkania Plus”, http://www.bankier.pl/wiadomosc/Potrzebne-choc-nierealne-deweloperzy-nie-boja-sie-Mieszkania-Plus-7420867.html (dostęp: 14 kwietnia 2017).

${ }^{25}$ Uchwała nr 115/2016 Rady Ministrów z dnia 27 września 2016 r. w sprawie przyjęcia Narodowego Programu Mieszkaniowego, s. 5, https://narodowyprogram.pl/wp-content/uploads/2017/03/uchwa\%C5\%82a_ narodowy_program_mieszkaniowy.pdf (dostęp: 16 kwietnia 2017).

${ }^{26}$ Ibidem, s. 16-17. 
1) zwiększenie liczby mieszkań przypadających na 1000 mieszkańców, w tym mieszkań dla osób o dochodach uniemożliwiających obecnie nabycie lub wynajęcie mieszkania na zasadach komercyjnych;

2) zmniejszenie liczby osób oczekujących na najem mieszkania gminnego, zagrożonych wykluczeniem społecznym ze względu na niskie dochody lub szczególnie trudną sytuację życiową;

3) zmniejszenie liczby osób mieszkających w warunkach substandardowych poprzez poprawę stanu technicznego zasobów mieszkaniowych oraz zwiększenie ich efektywności energetycznej ${ }^{27}$.

Tabela 10. Mierniki osiągnięcia celów Narodowego Programu Mieszkaniowego do roku 2030

\begin{tabular}{l|c|c|c|c}
\hline \multicolumn{1}{c|}{ Miernik/lata } & 2014 & 2020 & 2025 & 2030 \\
\hline $\begin{array}{l}\text { Liczba mieszkań przypadająca na 1000 } \\
\text { mieszkańców }\end{array}$ & 363 & 389 & 410 & 435 \\
\hline $\begin{array}{l}\text { Udział osób w wieku do 34 lat } \\
\text { zamieszkujących wspólnie } \\
\text { z rodzicami }\end{array}$ & $4,1 \%$ & $37 \%$ & $37 \%$ & $25 \%$ \\
\hline $\begin{array}{l}\text { Stosunek przeciętnego wynagrodzenia } \\
\text { netto w gospodarce narodowej do kosztu } \\
\text { budowy 1 m² mieszkania }\end{array}$ & $0,70(2015)$ & 0,78 & 0,90 & 1,05 \\
\hline $\begin{array}{l}\text { Liczba gospodarstw domowych } \\
\text { oczekujących na najem } \\
\text { mieszkania gminnego w tys. }\end{array}$ & 165,2 & 140 & 70 & 0 \\
\hline $\begin{array}{l}\text { Liczba osób zamieszkujących w warunkach } \\
\text { substandardowych (przeludnienie, } \\
\text { deprywacja) w tys. }\end{array}$ & 5360,2 & 4300 & 3800 & 3300 \\
\hline $\begin{array}{l}\text { Udział budynków ocieplonych w całości } \\
\text { zasobów }\end{array}$ & $\begin{array}{l}54,1 \% \\
(2012)\end{array}$ & $60 \%$ & $65 \%$ & $70 \%$ \\
\hline
\end{tabular}

Źródło: Uchwała nr 115/2016 Rady Ministrów z dnia 27 września 2016 r., s. 89.

Program zakłada, że w 2030 r. liczba mieszkań przypadająca na 1000 mieszkańców w Polsce powinna osiągnąć poziom zbliżony do średniej Unii Europejskiej. Jeszcze bardziej ambitne założenie dotyczy poprawy sytuacji mieszkaniowej rodzin oczekujących na najem mieszkania od gminy, gdyż w tym wypadku problem miałby być całkowicie rozwiązany. Również optymistyczne jest założenie osiągnięcia celu w postaci wyraźnego ograniczenia, gdyż o prawie $40 \%$, liczby osób mieszkających w budynkach o złym stanie technicznym lub też w mieszkaniach przeludnionych. Zakładane kierunki zmian $\mathrm{w}$ polskim mieszkalnictwie dobrze wpisują się $\mathrm{w}$ zalecenia unijne oraz krajowe dotyczące mieszkalnictwa. Ich realizacja może znacznie przybliżyć polskie mieszkalnictwo

27 Ibidem, s. 49-50. 
do standardów unijnych, a co najważniejsze, poprawić sytuację mieszkaniową polskich rodzin, także tych o przeciętnych i niskich dochodach.

\section{Podsumowanie}

Ocena zawsze jest trudna, zwykle sprowadza się do określenia status quo, zidentyfikowania czynników wywołujących zmiany oraz podania wniosków na przyszłość.

Dokonując próby oceny zmian w polskim mieszkalnictwie, można sformułować dwa spostrzeżenia. Po pierwsze, sytuacja ta zmieniła się korzystnie, choć nadal polskie rodziny mają sytuację gorszą niż mieszkańcy wielu krajów unijnych, głównie tych z grupy UE-15. Po drugie, zauważa się zbieżność kierunków realizowanej w Polsce polityki mieszkaniowej z głównymi dokumentami UE dotyczącymi mieszkalnictwa.

Podobną ocenę można sformułować także na podstawie analizy wyników badań Diagnoza Społeczna 2015. Wynika z nich również umiarkowanie pozytywna ocena zmiany sytuacji mieszkaniowej w Polsce w okresie członkostwa w UE. Wzrosło wówczas zadowolenie polskiego społeczeństwa z warunków życia, w tym także z warunków mieszkaniowych, jednakże wzrost ten był niższy od ogólnego wzrostu zadowolenia z życia oraz od wzrostu zadowolenia z sytuacji finansowej. W 2015 r. z sytuacji finansowej rodziny był zadowolony co trzeci badany, a w 2005 tylko co szósty, a więc wzrost był dwukrotny. Natomiast z warunków mieszkaniowych w 2015 r. zadowolonych było ponad połowę badanych $(55,3 \%)$ - wzrost zadowolenia w tym wypadku był mniejszy choć również wyraźny, bo o 5,9\% w porównaniu z rokiem 2005 (tabela 11) ${ }^{28}$.

Tabela 11. Poziom zadowolenia z warunków mieszkaniowych w Polsce w latach 2003-2015

\begin{tabular}{l|c|c|c|c|c|c|c}
\hline \multicolumn{1}{c|}{ Wyszczególnienie } & 2003 & 2005 & 2007 & 2009 & 2011 & 2013 & 2015 \\
\hline Zadowolenie z życia ogółem & 65,0 & 68,8 & 75,7 & 75,6 & 80,0 & 80,3 & 83,3 \\
\hline Zadowolenie sytuacji finansowej & 15,9 & 17,7 & 25,0 & 28,8 & 30,1 & 28,8 & 33,4 \\
\hline $\begin{array}{l}\text { Zadowolenie z warunków } \\
\text { mieszkaniowych }\end{array}$ & 47,5 & 49,4 & 50,4 & 50,6 & 53,1 & 53,2 & 55,3 \\
\hline
\end{tabular}

Źródło: Diagnoza Społeczna 2015...

Na poprawę sytuacji mieszkaniowej w Polsce w okresie dziesięciolecia niewątpliwie miała wpływ ogólna pozytywna zmiana sytuacji finansowej części polskich rodzin, wzrost nakładów finansowych państwa na cele mieszkaniowe, a także zmiana struktury tych nakładów na rzecz remontów mieszkań oraz Funduszu Dopłat wspierającego mieszkalnictwo społeczne oraz programy mieszkaniowe „Rodzina na swoim” i „Mieszkanie dla Młodych".

${ }^{28}$ Diagnoza Społeczna 2015..., s. 188. 
Zmiany w sytuacji mieszkaniowej polskich rodzin w okresie członkostwa w Unii Europejskiej pozwalają pozytywnie ocenić ogólne kierunki zmian w rodzimym mieszkalnictwie. Tym samym należałoby je kontynuować w przyszłości, z pewną jednak modyfikacją. Zważając na sytuację materialną polskiej rodziny, choć ulegającą ciągłej poprawie, wysokie ceny mieszkania, jak i wysokie koszty jego utrzymania, należałoby zwiększać nakłady na mieszkalnictwo społeczne, sprzyjające zaspokojeniu potrzeb mieszkaniowych mniej zamożnych rodzin. Nadzieje na realizację tego kierunku stanowi Narodowy Program Mieszkaniowy, w tym też wdrażany już program „Mieszkanie Plus”.

\section{Bibliografia}

Andrzejewski A., Mieszkanie jako element środowiska materialnego i społecznego - funkcje i forma mieszkania, [w:] Przeszłość i przyszłość polskiej polityki mieszkaniowej, red. L. Frąckiewicz, Instytut Pracy i Spraw Socjalnych, Instytut Gospodarki Nieruchomościami, Warszawa-Katowice 2005.

Bezpośrednie wydatki budżetu państwa na sferę mieszkaniową, http://mib.gov.pl/files/0/1796792/Wydatkibudzetupanstwanasferemieszkaniowaod1995.pdf.

Cesarski M., Polityka mieszkaniowa w Polsce w pracach naukowych 1918-2010. Dokonania i wplyw polskiej szkoły badań, Oficyna Wydawnicza SGH, Warszawa 2013.

Dane liczbowe programu „Rodzina na swoim”, Bank Gospodarstwa Krajowego 2014, www.bgk.pl/files/ public/Pliki/Klienci_indywidualni/rodzina_na_swoim/Dane_liczbowe_do_31_grudnia_2013.pdf.

Diagnoza Społeczna 2015. Warunki i jakość życia Polaków, red. J. Czapiński, T. Panek, Rada Monitoringu Społecznego, Warszawa 2015, http://www.diagnoza.com.

Europejska Karta Społeczna sporządzona w Turynie dnia 18 października 1961 r., Dz.U. z dnia 29 stycznia 1999 r., www.mpips.gov.pl/spoleczne-prawa-czlowieka/rada-europy-europejska-karta-spoleczna/.

Eurostat (ilc_lvho05a), (ilc_mdho06a), (ilc_lvho02), (ilc_lvho07a).

Karta Praw Podstawowych Unii Europejskiej, Dziennik Urzędowy Unii Europejskiej 2007/C 303/1, http:// bip.kprm.gov.pl/ftp/kprm/dokumenty/080226u1karta.pdf.

Konstytucja Rzeczypospolitej Polskiej z dnia 2 kwietnia 1997 r., Dz.U. z 1997 r. Nr 78, poz. 483.

Księżopolski M., Polska polityka społeczna na tle modeli występujących w Europie, [w:] Europa socjalna. Iluzja czy rzeczywistość, red. W. Anioł, M. Duszczyk, P.W. Zawadzki, Oficyna Wydawnicza ASPRA-JR, Warszawa 2011.

Kurowski P., Broda-Wysocki P., Ubóstwo mieszkaniowe: oblicza, trendy, wyzwania, „Polityka Społeczna” 2017, nr 2 .

Mieszkanie dla młodych, http://mib.gov.pl/2-MieszkaniedlaMlodych.htm.

Muzioł-Więcławowicz A., Problemy mieszkaniowe Polaków a polska polityka mieszkaniowa, [w:] Mieszkalnictwo w Polsce, red. M. Salamon, A. Muzioł-Więcławowicz, Habitat for Humanity Poland, Warszawa 2015.

OECD Questionnaire on Affordable and Social Housing, http://www.oecd.org/social/affordable-housingdatabase.htm.

Polityka państwa wobec rodziny, BS/67/2012, Centrum Badania Opinii Społecznej, Warszawa 2012, http:// www.cbos.pl/SPISKOM.POL/2012/K_067_12.PDF.

Potrzebne, choć nierealne - deweloperzy nie bojq się „Mieszkania Plus”, http://www.bankier.pl/wiadomosc/ Potrzebne-choc-nierealne-deweloperzy-nie-boja-sie-Mieszkania-Plus-7420867.html.

Raport AMRON-SARFiN. Ogólnopolski Raport o Kredytach mieszkaniowych i cenach transakcyjnych nieruchomości, nr 1/2014-4/2016, http://zbp.pl/raporty/raport-amron-sarfin.

Rezolucja Parlamentu Europejskiego z dnia 10 maja 2007 r. w sprawie mieszkalnictwa i polityki regionalnej, http://www.europarl.europa.eu/sides/getDoc.do?pubRef=-//EP//TEXT+TA+P6-TA-2007$0183+0+\mathrm{DOC}+\mathrm{XML}+\mathrm{V} 0 / / \mathrm{PL}$. 
Rezolucja Parlamentu Europejskiego z dnia 11 czerwca 2013 r. w sprawie budownictwa socjalnego w Unii Europejskiej, http://www.europarl.europa.eu/sides/getDoc.do?pubRef=-//EP//TEXT+TA+P7-TA-2013-0246+0+DO$\mathrm{C}+\mathrm{XML}+\mathrm{V} 0 / / \mathrm{PL}$.

Supińska J., Zubrzycka-Czarnecka A., Polskie mieszkalnictwo w erze integracji europejskiej - punkt wyjścia, ścieżki rozwoju, [w:] Dekada członkostwa w Unii Europejskiej. Perspektywa polityki społecznej, red. C. Żołędowski, B. Rysz-Kowalczyk, M. Duszczyk, Wydawniczy ELIPSA, Warszawa 2015.

Uchwała nr 115/2016 Rady Ministrów z dnia 27 września 2016 r. w sprawie przyjęcia Narodowego Programu Mieszkaniowego, https://narodowyprogram.pl/wp-content/uploads/2017/03/uchwa\%C5\%82a_narodowy_program_mieszkaniowy.pdf.

Ustawa z dnia 8 września 2006 r. o finansowym wsparciu rodzin w nabywaniu własnego mieszkania. Dz.U. z 2006 r. Nr 183, poz. 1354 ze zm.

ZrewidowanaEuropejskaKartaSpołeczna,www.mpips.gov.pl/aktualnosci-wszystkie/art,5535,4326,podpisaniezrewidowanej-europejskiej-karty-spolecznej.html.

Zubrzycka-Czarnecka A., Instrumenty i ograniczenia unijnej polityki mieszkaniowej, [w:] Europa socjalna. Iluzja czy rzeczywistość, red. W. Anioł, M. Duszczyk, P.W. Zawadzki, Oficyna Wydawnicza ASPRA-JR, Warszawa 2011.

\section{Is housing in Poland moving towards European standards?}

Keywords: housing functions, housing situation of the EU, Polish housing programs

\section{Summary}

This article approximates changes in the housing situation in Poland during the period of membership of the European Union. It is also an attempt to reflect on whether the ongoing changes in housing in Poland are moving towards European standards. The Polish government has adopted the National Housing Program in 2016, which sets out the key goals, thus setting the direction for changes in housing. Generally, the idea is to increase the supply of housing, including those that could serve the needs of low-income families, preventing them from purchasing or renting a home on a commercial basis. The program also aims to improve housing conditions, among other things. By reducing overcrowding and deprivation of housing. 